\title{
NFKB2 wt Allele
}

National Cancer Institute

\section{Source}

National Cancer Institute. NFKB2 wt Allele. NCI Thesaurus. Code C53098.

Human NFKB2 wild-type allele is located in the vicinity of 10q24 and is approximately $8 \mathrm{~kb}$ in length. This allele, which encodes nuclear factor NF-kappa-B p100 subunit protein, is involved in the modulation of transcription by RNA polymerase II. A variety of leukemias and lymphomas are associated with translocations $\mathrm{t}(10 ; 14)(\mathrm{q} 24 ; \mathrm{q} 11)$ of the gene and the T-cell receptor alpha or delta locus, or $t(10 ; 14)(q 24 ; q 32)$ of this gene and the IGHA1 locus. 